\title{
SOSIALISASI TEKNIK PENULISAN ARTIKEL JURNAL ILMIAH UNTUK MENGEMBANGKAN KETERAMPILAN MENULIS PESERTA DIDIK
}

\author{
Nurul Maulida Alwi \\ Jurusan Bimbingan dan Konseling, Universitas Negeri Gorontalo, Gorontalo \\ E-mail: maulidanurul@ung.ac.id
}

\begin{abstract}
Abstrak
Sosialisasi teknik penulisan artikel jurnal ilmiah merupakan kegiatan untuk mengembangkan keterampilan menulis peserta didik. Kemampuan literasi peserta didik perlu dikembangkan guna menambah wawasan berpikir dalam membuat karya tulis ilmiah berupa artikel jurnal. kegiatan ini bertujuan untuk memaksimalkan minat menulis peserta didik dan agar memiliki kemampuan untuk mengikuti kompetisi. Selain itu kegiatan ini bertujuan agar peserta didik mengetahui sitematika penulisan artikel jurnal ilmiah sehingga menjadi bekal wawasan untuk mengembangkan kemampuan literasi berikutnya. Persiapan dan pelaksanaan kegiatan dilakukan selama sebulan di sekolah MAN 1 Boalemo, Kecamatan Tilamuta, Kabupaten Boalemo, Provinsi Gorontalo. Metode yang digunakan yaitu ceramah, diskusi dan tutorial. Kegiatan terdiri dari tahap persiapan awal yaitu merumuskan masalah, membuat rancangan kegiatan, membuat surat tugas, mengumpulkan literatur, membuat materi presentasi kegiatan. Kemudian tahap kedua yaitu pelaksana memberikan 5 sesi pada kegiatan yaitu sesi pertama membangun support atau pembukaan, sesi kedua yaitu pemberian Materi dalam bentuk ceramah dengan bantuan power point yang berisikan pembelajaran dalam menulis jurnal dari tahap ke tahap mulai dari penjelasan cara membuat menentukan judul, pendahuluan, metode, hasil dan pembahasan, simpulan dan saran, cara membuat kutipan serta cara membuat referensi. Sesi ketiga yaitu simulasi. Kemudian, sesi keempat dilakukan coaching kepada peserta didik terkait sistematika pembuatan karya tulis ilmiah khususnya jurnal. Di sesi kelima telah diadakan refleksi mengenai kegiatan untuk lebih memaknai proses sosialisasi secara optimal, mengumpulkan dokumentasi dan menentukan hasil evaluasi kegiatan yaitu siswa memiliki peningkatan pemaham mengenai teknik penulisan artikel jurnal ilmiah, peserta kegiatan yaitu 35 orang peserta didik di sekolah MAN 1 Boalemo.
\end{abstract}

Kata Kunci: Sosialisasi, Teknik Penulisan, Artikel Jurnal Ilmiah, Keterampilan Menulis, Peserta Didik.

\begin{abstract}
Socialization of scientific journal writing techniques is an activity to develop students' writing skills. The literacy skills of students need to be developed in order to add insight into thinking in making scientific writings as a form of journal articles. This activity aims to maximize the interest of students and to have the ability to join a compete. In addition, this activity aims to make students know the systematics of writing scientific articles so that they become a provision of insight to develop subsequent literacy skills. The preparation and implementation of activities was carried out for a month at the MAN 1 Boalemo school, Tilamuta District, Boalemo Regency, Gorontalo Province. The methods used are lectures, discussions and tutorials. The activity consists of the initial preparation stage, namely formulating problems, making activity plans, making assignment letters, collecting literature, making activity presentation materials. Then the second stage is the executor gave 5 activities, namely the first session building support or opening, the second session providing material in the form of lectures with the help of power points containing learning in journal writing from stage to stage starting from an explanation of how to determine the title, introduction, method, results. and discussion, conclusions and suggestions, how to quote and how to make references. The third session is simulation. Then, in the fourth session, coaching was carried out for students related to the systematics of making scientific works, especially journals. In the fifth session, there were reflections on activities to better interpret the process optimally, collected the documentation and determine the results of the evaluation of activities that is students had an increased understanding of the technique of writing
\end{abstract}


scientific journal articles, the participants of the activity are 35 students at MAN 1 Boalemo school.

Keywords: Socialization, Writing Techniques, Scientific Journal Articles, Writing Skills, Students.

\section{PENDAHULUAN}

Pendidikan di Indonesia secara umum bertujuan untuk mencerdaskan anak bangsa yang akan berdampak pada kesejahteraan perkembangan bangsa agar generasi penerus mampu menjaga dan menerapkan nilai-nilai kehidupan, mampu mengembangkan pemikiran dari hasil belajar, mampu meningkatkan keterampilan dan kreativitas sehingga menjadi sebuah inovasi yang memiliki nilai pengembangan dan kebaharuan serta mampu mengikuti perkembangan globalisasi. Fungsi pendidikan yaitu agar kemampuan atau potensi dapat berkembang, terbentuknya watak, kepribadian, memanusiakan manusia, mengembangkan keterampilan hidup agar peserta didik mendapatkan kehidupan yang baik dan dalam rangka mencerdaskan kehidupan bangsa maka diperlukan peradaban bangsa yang bermartabat (Haderani, 2018; Sujana, 2019) Peserta didik diharapkan mampu melakukan dan memperoleh hal tersebut dan tidak merasa dipaksakan. Pendidikan memiliki tingkatan yang disesuaikan dari usia dan tahap kemampuan belajar yaitu pada tahap operasional konkret, peserta didik berada di usia 6-12 tahun berada pada jenjang Pendidikan Anak Usia Dini (PAUD) Pendidikan Sekolah Dasar (SD), pada tahap operasional formal peserta didik berusia 12 tahun ke atas dan berada pada jenjang pendidikan Sekolah Menengah (MTS/SMP/MAN/SMA).

Perkembangan kognitif peserta didik yang berada di tahap usia operasional formal menurut piaget (Jariah, 2021) yaitu peserta didik telah mampu berpikir logis, abstrak dan menentukan hipotesis serta mampu menentukan arah proses berpikirnya. Pada usia ini tidak hanya dilihat dari perkembangan kognitifnya melainkan juga perkembangan motorik yang telah dapat membuat tulisan-tulisan ilmu pengetahuan baik itu yang bersifat fiksi maupun non fiksi. Dari hasil proses berpikir dan melalui tindakan, peserta didik dapat menuangkan ide-ide ke dalam bentuk tulisan. Salah satu bentuk tulisan yang diketahui yaitu karya tulis seperti jurnal ilmiah.

Keterampilan menulis merupakan salah satu kompetensi dari pembelajaran bahasa yang merupakan pusat berbagai pengetahuan dan diperoleh dari kegiatan membaca, menyimak dan mengucapkan kata kemudian membentuk sebuah rangkaian kata dan kalimat sehingga menjadi bahasa yang bermakna juga memiliki tujuan (Helaluddin \& Awalludin, 2020; Gusrita, 2021). Hal ini sejalan dengan pendapat Drani, et al. (2021) dan Sumardi, et al. (2020), bahwa untuk memiliki keterampilan menulis, maka memulainya dengan menghubungkan pada ide dan gagasan, perasaan maupun pikiran yang dipikirkan dan dirasakan kedalam bentuk sebuah tulisan. Tujuan penerapan dari keterampilan menulis yaitu menggunakan item yang terstruktur pada tahap dipelajari sebelumnya dengan cara mengkomunikasikan informasi atau pesan yang diperoleh (Anggraini \& Lume, 2021). Abidin (2015), mengemukakan bahwa di abad 21 terdapat tiga hal konsep standar pembelajaran menulis memiliki standar inti pada pembelajaran menulis internasional dari jenjang pendidikan dasar hingga pada pendidikan tinggi yaitu memilih secara efektif mengenai penulisan narasi untuk mengembangkan pengalaman, kenyataan, dan imajinasi menggunakan struktur cerita secara detail dari suatu peristiwa, menulis teks informatif eksplanatori secara jelas, menyampaikan ide atau informasi yang kompleks, akurat dengan melakukan seleksi, organisasi, menganalisis isi secara selektif; mendukung hasil analisis terhadap topik substantif dengan menggunakan beberapa alasan melalui argumen.

Saat ini peserta didik MAN 1 Boalemo memiliki minat menulis yang rendah dikarenakan 
beberapa publikasi jurnal masih sedikit yang dimiliki oleh para peserta didik di tingkat MAN 1 Boalemo, beberapa peserta didik diketahui memiliki keterampilan menulis dalam bentuk buku novel hal ini wajar karena sesuai dengan tingkat berpikir peserta didik yang lebih imajinatif. Akan tetapi, jika peserta didik memiliki kemampuan dalam menulis karya ilmiah khususnya jurnal maka dapat meningkatkan pengembangan kognitif dan psikomotorik peserta didik. Selain itu, keterampilan menulis peserta didik juga berkembang karena mampu menulis melalui proses berpikir ilmiah, menyusun konteks secara terstruktur dan mampu menganalisa secara detail bentuk peristiwa, metode, hasil dan mampu memberikan kesimpulan secara rinci. Hal ini merupakan bentuk perkembangan kognitif peserta didik diusia remaja yang mampu berfikir logis, mampu melihat permasalah serta mampu berfikir untuk menentukan solusi yang tepat secara mandiri.

Karya tulis ilmiah memiliki maksud dan tujuan seperti mampu menuangkan ide ataupun pemikiran dalam bentuk tulisan guna menyajikan hasil pengkajian secara ilmiah, mencatat, memberitahukan, dan merekomendasikan hasil penelitian (Kristanto, 2018; Slameto, 2016). Selain itu, bertujuan agar memperoleh pengetahuan dan pemahaman dalam menulis artikel jurnal ilmiah (Susetyo et al., 2020) serta meningkatkan pengembangan ilmu pengetahuan dan pengembangan karir peneliti maupun akademisi (Hajar et al., 2020). Keterampilan menulis jurnal memiliki manfaat yang dapat memotivasi peserta didik untuk berkarya. Sesuai tahap perkembangan remaja, peserta didik tingkat MAN memiliki daya imajinasi yang tinggi, mampu menemukan ide dan gagasan yang menarik untuk dikembangkan secara inovatif dan terstruktur, sehingga jika terbiasa menulis maka tingkat kepekaan diri terhadap suatu memontem yang telah ada dapat diperoleh melalui menulis artikel jurnal yang aktual dan relevan dengan keadaan yang sedang berkembang maupun data-data yang tersedia dapat dimanfaatkan (Winarto, W, W, 2021).

Jika kemampuan peserta didik dalam menulis artikel jurnal dapat dikembangkan maka akan berdampak positif pada publikasi ilmiah tidak hanya secara nasional melainkan dapat dipublikasikan secara internasional. Peserta didik yang telah memiliki karya tulis ilmiah dapat dijadikan sebuah artikel jurnal melalui tahap menyusun hasil investigasi dalam bentuk proposal penelitian yang telah dirancang, bersifat objektif dan komprehensif serta memiliki unsur kebaruan bahwa dapat diakui yang memiliki kontribusi nyata (Setiyo, 2021). Berdasarkan survei yang telah dilakukan di sekolah MAN 1 Boalemo, Kecamatan Tilamuta, Provinsi Gorontalo yaitu tiap tahun peserta didik selalu mengikuti lomba karya tulis ilmiah dan jumlahnya tidak dibatasi untuk mengirimkan karya tulis ilmiah serta membuat luarannya berupa artikel jurnal. Akan tetapi, pemahaman peserta didik sangat terbatas mengenai sistematika penulisan karya tulis ilmiah apalagi mengenai teknik penulisan artikel jurnal. Beberapa diantara mereka sangat inisiatif untuk mempelajari metode penulisan jurnal. Peserta didik ingin karya dan ide yang telah dituangkan dalam bentuk tulisan dapat dibaca oleh para pembaca artikel jurnal.

Pengembangan keterampilan menulis artikel jurnal di sekolah MAN 1 Boalemo ini sangat dibutuhkan dan bermanfaat untuk peserta didik karena dari hasil wawancara bebas yang telah dilakukan dari pihak sekolah bahwa setiap tahun sering ada kompetisi dalam membuat artikel jurnal yaitu madrasah young researcher super camp. Jenis kompetisi ini sangat membantu peserta didik untuk terus belajar dan berpikir, menemukan ide yang kreatif, dan mengembangkan keterampilan menulis sehingga hasil karya tulis yang dibuat oleh peserta didik dapat dijadikan sebuah artikel jurnal.

\section{METODOLOGI PENGABDIAN}

Sasaran strategi dalam kegiatan ini yaitu peserta didik MAN 1 Boalemo, Kecamatan Tilamuta, Kabupaten Boalemo, Provinsi Gorontalo berjumlah 35 orang yang akan memperoleh layanan informasi mengenai sosialisasi teknik penulisan artikel jurnal untuk mengembangkan keterampilan menulis. Metode yang digunakan yaitu ceramah, diskusi dan tutorial. Pelaksana memberikan materi dalam bentuk ceramah dengan bantuan power point yang berisikan materi. 
Kegiatan ini dimulai dari tahap persiapan awal yaitu merumuskan masalah dengan membangun komunikasi dengan kepala sekolah mengenai kebutuhan peserta didik dalam mengembangkan keterampilan menulis artikel jurnal, membuat rancangan kegiatan, membuat surat tugas sebagai bentuk kerja sama, mengumpulkan literatur yang mudah dipahami oleh peserta didik, membuat materi presentasi kegiatan dan serta pada tahap pelaksana dalam kegiatan memiliki waktu kegiatan berlangsung selama 5 sesi yaitu membangun rapport atau pembukaan, pemberian materi yaitu penjelasan cara membuat menentukan judul, pendahuluan, metode, hasil dan pembahasan, simpulan dan saran, cara membuat kutipan serta cara membuat referensi, sesi ketiga simulasi, sesi keempat yaitu kegiatan coaching dan sesi terakhir adalah penutup.

\section{PELAKSANAAN KEGIATAN}

Diawali dengan tahap pertama yaitu persiapan awal yaitu merumuskan jenis kebutuhan yang diperlukan peserta didik untuk meningkatkan keterampilan menulis artikel jurnal yaitu peserta didik membutuhkan bimbingan teknik menulis artikel jurnal ilmiah dari hasil karya tulis atau penelitian yang telah dibuat. Kemudian tahap kedua yaitu membuat rancangan bentuk kegiatan dan pelaksanaanya dilakukan dengan mengatur jadwal kegiatan sesuai dengan kesepakatan bersama dan termasuk membuat catatan persiapan media yang dibutuhkan misalnya, laptop, LCD, ruangan, kursi, spanduk, microphone dan lainnya serta tetap menydiakan alat untuk menjaga protokol kesehatan

Tahap ketiga membuat surat tugas sebagai bentuk kerja sama antara pihak sekolah dan pelaksana kegiatan. Kemudian tahap keempat yaitu mengumpulkan literatur atau bahan referensi untuk dijadikan materi dalam kegiatan sehingga presentasi dan bimbingan dapat terlaksana dengan lancar dan terarah. Tahap kelima yaitu membuat materi dari hasil literatur yang terkumpulkan, materi dibuat dengan menggunakan bahasa yang mudah dipahami oleh peserta didik dan jelas. Pembuatan materi memerlukan waktu hampir seminggu sehingga pelaksanaan kegiatan dilaksanakan di akhir bulan.

Tahap akhir yaitu pelaksanaan kegiatan diadakan, pada tahap ini peserta didik dengan senang hati dan memberikan respon positif kepada pelaksana karena semuanya berpartisipasi aktif dalam pemberian materi dan tahap coaching. Tema dalam kegiatan ini yaitu Riset, Penulisan, dan Publikasi Karya Tulis Ilmiah. Kegiatan ini diadakan untuk memberikan pemahaman tentang menulis artikel jurnal kepada peserta didik ketika telah melakukan penelitian. memaksimalkan minat menulis peserta didik dan agar memiliki kemampuan kompetisi. Selain itu kegiatan ini bertujuan agar peserta didik mengetahui sitematika penulisan jurnal sehingga menjadi bekal wawasan untuk mengembangkan kemampuan literasi berikutnya. kegiatan pada pengabdian ini terdiri dari 5 sesi, yaitu pada sesi pertama, pelaksana melakukan pembukaan dengan cara membangun rapport atau hubungan yang baik kepada peserta didik pada pembukaan, seperti melakukan senyum, sapa dan salam, menanyakan pengalaman peserta didik dalam menulis karya tulis ilmiah, membangun paradigma berpikir untuk meningkatkan motivasi internal peserta didik.

Pada sesi kedua, pelaksana memberikan materi yang dapat membuat peserta didik paham mengenai sistematika penulisan karya tulis ilmiah dan luarannya khususnya artikel jurnal. Pada sesi ketiga, pelaksana menciptakan suasana kelas menjadi lebih menyenangkan dengan cara melatih konsentrasi peserta didik melalui beberapa jenis simulasi, pada sesi keempat pelaksana mengadakan coaching khusus dalam bentuk kelompok dimulai dari cara pembuatan judul, cara mendapatkan referensi terpercaya hingga sistematika atau teknik pembuatan artikel jurnal secara umum dan pada tsesi kelima atau akhir, pelaksana melakukan sesi penutup dengan melakukan refleksi mengenai kegiatan yang telah dilakukan untuk lebih memaknai proses pelatihan secara optimal, menentukan hasil evaluasi kegiatan, menyusun laporan dan dokumentasi kegiatan. 


\section{HASIL DAN PEMBAHASAN}

Setelah tahap persiapan awal yaitu merumuskan masalah, membuat rancangan kegiatan, membuat surat tugas, mengumpulkan literatur, membuat materi presentasi kegiatan telah dilaksanakan dan tidak memiliki banyak hambatan dan hasil pada tahap pelaksanaan ini terdiri dari 5 sesi yaitu sesi pembukaan, sesi pemberian materi, sesi simulasi, sesi coaching, dan sesi penutupan. Kegiatan penulisan artikel jurnal ilmiah dilakukan kepada peserta didik tingkat madrasah aliyah di MAN 1 Boalemo untuk memberikan pemahaman dan strategi pembuatan jurnal baik itu dari sisi pengertian pembuatan jurnal hingga sistematikanya. Pada sesi pembukaan pelaksana membangun rapport kepada peserta didik agar tercipta suasana yang kondusif, nyaman, adanya rasa penerimaan dan peserta didik secara sukarela untuk menambah wawasan berpikir ilmiah serta memastikan kesiapan peserta didik mengikuti kegiatan penulisan. Pada sesi ini pelaksana membantu peserta didik untuk meningkatkan motivasi internal dan peserta didik sangat berperan aktif dalam mengetahui cara membuat karya tulis ilmiah dan khususnya pada luarannya berupa jurnal, karena tidak banyak yang mengetahui tujuan dan manfaat pembuatan artikel jurnal. Pada sesi ini, beberapa peserta didik antusias untuk memberikan pertanyaan mengenai pengertian jurnal dan proses pembuatannya dimulai dari mana saja, untuk itu pelaksana memberikan pemahaman mengenai jurnal lebih detail yang akan dibahas pada sesi kedua yaitu pemberian materi.

Pada sesi kedua, bentuk kegiatan yang diberikan yaitu pemberian materi mengenai sistematikan penulisan karya tulis ilmiah khususnya pada penulisan jurnal. Dimulai dari penentuan judul tentang bagaimana tips dalam memilih judul sesuai dengan permasalahan atau peristiwa yang sedang terjadi dan membutuhkan solusi dan inovasi, cara menentukan judul sesuai dengan kondisi kekinian, dan mengembangkan suatu ide yang telah sebelumnya. Kemudian tips kedua memberikan penjelasan tentang cara membuat pendahuluan yang pada umumnya diketahui dengan istilah "segitiga terbalik" artinya setiap paragraf dimulai dari hal umum yang dapat diutarakan dan deskripsikan dalam bentuk tulisan kemudian menspesifikasikan dalam bentuk data yang diperoleh beserta cara mencari dan meletakkan analisis gap atau hasil-hasil penelitian sebelumnya ke dalam sebuah artikel jurnal. Selanjutnya tips ketiga yaitu membuat metode yang sesuai dengan metode penelitian yang dilakukan. Proses mentukan metode tentunya dapat diketahui dari beberapa bentuk penelitian baik itu dalam bentuk kuantitatif maupun kualitatif.

Tips berikutnya yaitu menentukan hasil dan pembahasan. Peserta didik belajar untuk membedakan konten dari hasil penelitian dimulai dari mencantumkan tabulasi atau diagram data yang diperoleh kemudian dijelaskan secara singkat dan detil kemudian dilanjutkan penjelaan tentang pembahasan penelitian dimulai dari deskripsi variabel dan fenomena yang terjadi dilapangan serta usaha yang diterapkan dalam penelitian sehingga penelitan dapat berjalan dengan lancar dan sesuai dengan tujuan. Tips berikutnya yaitu simpulan dan saran yaitu meringkas secara rinci dan jelas hasil dari penelitian dan memberikan saran tentang kekurangan dan memberitahukan hal-hal yang dapat dikembangkan lagi dari penelitian yang telah dilakukan. Tips berikutnya yaitu membuat kutipan dan kajian pustaka dengan menyarankan untuk menggunakan aplikasi referensi bawaan dari Ms. Word, Mendeley ataupun Zotero. Selain dari itu pelaksana juga menunjukan susunan dari tiap jurnal beserta aturan penulisan yang biasanya digunakan. Pemberian materi diperlihatkan pada Gambar 1.

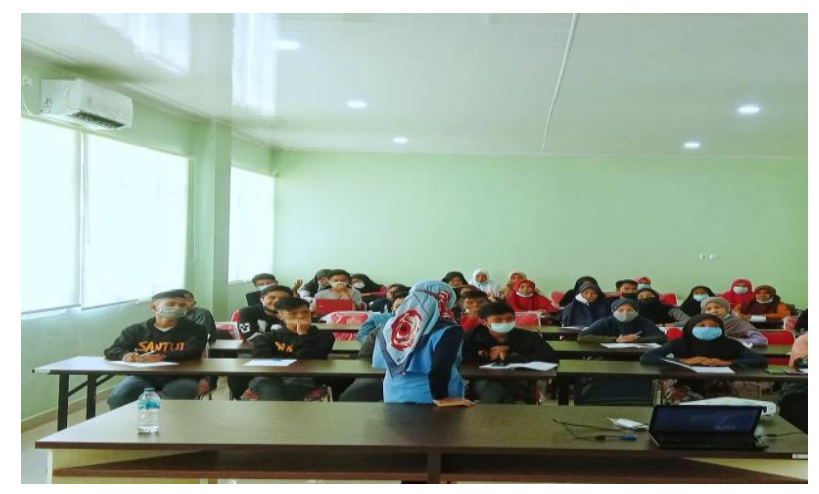

Gambar 1. Pemberian materi

Pada sesi ketiga yaitu pelaksanaan simulasi, pelaksana memberikan beberapa hiburan agar peserta didik tetap aktif dan bisa fokus dalam mengikuti materi selanjutnya. Kegiatan simulasi ini dilakukan sebagai bagian dari sesi kegiatan yang bertujuan untuk meningkatkan minat belajar dalam membuat karya tulis ilmiah khuusnya jurnal 
ilmiah. Jenis simulasi yang diberikan yaitu memperhatikan bentuk dan kata dari objek yang disebutkan oleh pelaksana dengan cara merespon kebalikan dari bentuk yang disebutkan.

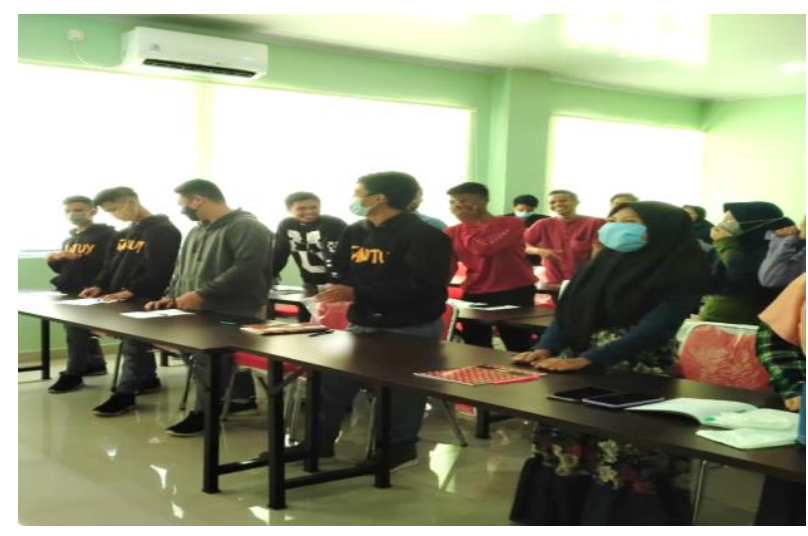

Gambar 2. Simulasi/Hiburan

Kemudian mengikuti objek yang ditunjukkan pelaksana dengan cepat dan menyebutkan kata salam yang berbeda dari pelaksana sesuai kata yang telah disepakati bersama. Setelah mengikuti simulasi, peserta didik menjadi lebih senang karena telah diberikan stimulus hiburan dan siap untuk aktif dalam sesi kegiatan selanjutnya seperti yang terlihat pada Gambar 2.

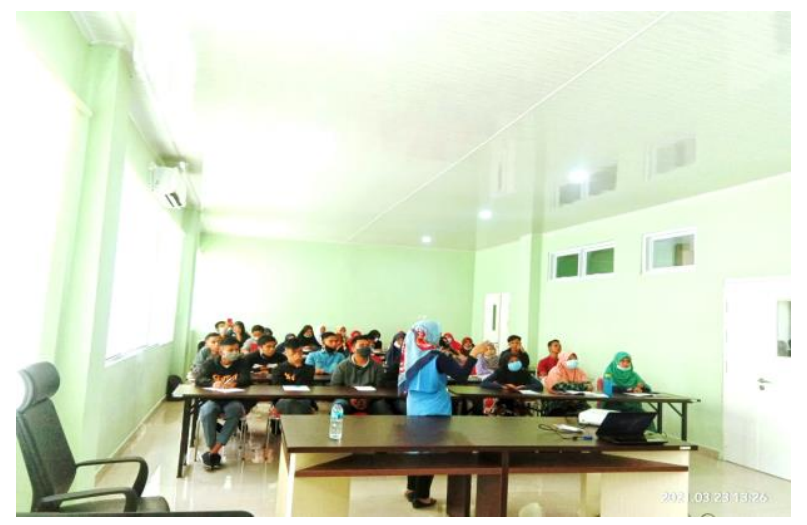

Gambar 3. Coaching

Pada sesi keempat, sesuai Gambar 3. dilakukan coaching pada beberapa kelompok mengenai konsultasi judul dan sistematika penulisan jurnal setelah melakukan penelitian. Konsultasi yang diberikan terhadap setiap peserta didik yang berada dalam kelompok dengan durasi waktu kurang lebih 40 menit sehingga dapat terpenuhi segala pertanyaan dan masukan yang diberikan oleh pelaksana. Peserta didik yang mengikuti kegiatan penulisan jurnal ada yang telah memiliki pengalaman dan ada yang baru pertama kali mengenal penulisan jurnal ilmiah sehingga pelaksana menjelaskan secara jelas mengenai bentuk-bentuk penulisan jurnal yang baik sehingga ketika mereka mengikuti lomba karya tulis ilmiah tingkat madrasah, mereka mampu membuat karya tulis ilmiah dengan baik serta mampu membuat hasil penelitian menjadi satu bahan bacaan yang dapat dipublikasikan dalam bentuk artikel jurnal.

Pada sesi kelima, pelaksana menutup kegiatan dengan cara memberikan kesempatan kepada peserta didik untuk merefleksikan kembali pengetahuan yang mereka peroleh dari kegiatan penulisan karya tulis ilmiah khusnya membuat artikel jurnal. Pada sesi ini peserta didik antusias mengacungkan tangan untuk memberikan pengertian tentang jurnal, manfaat dan sistematika penulisannya serta menjelaskan bentuk penelitian yang akan mereka buat terlebih dahulu dalam bentuk proposal yang akan mereka ikuti dalam ajang lomba menulis karya tulis ilmiah tingkat madrasah yang informasinya dapat diperoleh dari sekolah dan tahap selanjutnya yang dilakukan pelaksana yaitu dan melengkapi dokumentasi kegiatan dan menentukan hasil evaluasi kegiatan bahwa peserta didik telah memahami teknik penulisan artikel jurnal ilmiah ditandai dari hasil kegiatan yakni dari beberapa peserta didik menyampaikan telah memperoleh pengetahuan tentang teknik penulisan artikel jurnal yang sebelumnya masih menganggap berupa makalah atau proposal dan sekarang dapat membedakan sistematika dari penulisan artikel jurnal ilmiah.

\section{Ucapan Terima Kasih}

Terima kasih Kepada kepala sekolah, guru, staf dan para peserta didik Man I Boalemo Kecamatan Tilamuta, Kabupaten Boalemo, Provinsi Gorontalo, karena telah mendukung dan berpartisipasi secara aktif dalam mengefektifkan kegiatan pengabdian ini.

\section{PENUTUP \\ Kesimpulan}

Pemberian sosialisasi teknik penulisan artikel jurnal untuk mengembangkan keterampilan menulis anak dapat berjalan secara efektif ditandai 
dengan para peserta didk berpartisipasi aktif dalam setiap sesi khususnya dalam pemberian materi dan coaching. Selain itu, kegiatan ini bertujuan agar peserta didik dapat mengetahui sitematika penulisan jurnal sehingga menjadi bekal wawasan untuk mengembangkan kemampuan literasi yang dimiliki. Terdapat 5 sesi yang diberikan dalam kegiatan ini yaitu sesi pertama pembukaan atau membangun rapport sehingga peserta didik memiliki niat dan dapat berpartisipasi aktif dalam kegiatan pengabdian, yang kedua pemberian materi kepada peserta didik dimulai dari cara menentukan judul hingga penulisan daftar pustaka, kemudian sesi simulasi untuk menghibur peserta didik dan dilanjutkan pada sesi keempat kegiatan coaching atau mendampingi peserta untuk menentukan judul dan bagaimana menentukan metode serta mendeskripsikan hasil dan pembahasannya kemudian yang terakhir penutup diadakan refleksi mengenai kegiatan yang telah dilakukan untuk lebih memaknai proses kegiatan secara optimal, menentukan hasil evaluasi kegiatan, menyusun laporan dan dokumentasi kegiatan.

\section{Saran}

Pada kegiatan selanjutnya lebih ditingkatkan pendampingan lanjutan secara intensif dari guru-guru di sekolah agar peserta didik dapat terus mengembangkan keterampilan menulis baik itu artikel jurnal ataupun proposal dan laporan penelitian. Saran bagi penikmat pendidik dan penulis lainnya dapat melakukan kegiatan pengabdian yang serupa untuk meningkatkan minat literasi sehingga keterampilan menulis peserta didik dapat berkembang.

\section{DAFTAR PUSTAKA}

Abidin, Y. (2015). Pembelajaran Multiliterasi: Sebuah Jawaban Atas Tantangan Pendidikan Abad Ke-21 dalam Konteks Keindonesiaan. Rafika Aditama.

Anggraini, S. W. P., \& Lume, L. (2021). the Effectiveness of Using Chronological Paragraph Strategy Toward Students' Writing Skill. Journal of Languages and Language Teaching, 9(1), 77. https://doi.org/10.33394/jollt.v\%vi\%i.3065
Drani, A., Adisaputera, A., \& Wuriyani, E. P. (2021). Effectiveness of Using Folklore TextBased Learning Media Literacy in Class X Students of MAN Tg. Pura. Budapest International Research and Critics in Linguistics and Education (BirLE) Journal, 4(1), 377-391. https://doi.org/10.33258/birle.v4i1.1625

Gusrita, T. (2021). Penerapan Model Pembelajaran Berbasis Masalah untuk Meningkatkan Keterampilan Menulis Teks Eksposisi Peserta didik MAN 1 Sarolangun. Jurnal Pendidikan Guru, 2(1), 103-110.

Haderani. (2018). Tinjauan Filosofis tentang Fungsi Pendidikan dalam Hidup Manusia. Jurnal Tarbiyah: Jurnal Ilmiah Kependidikan, 7(1), 41-49. https://doi.org/10.18592/tarbiyah.v7i1.2103

Hajar, I., Fatah, M. C., Ispranyoto, E., Yogiyanto, A., Yuliansyah, Y., \& Legino, S. (2020). Pelatihan Penulisan Jurnal Ilmiah untuk Civitas Akademika Universitas Brawijaya Malang. Terang: Jurnal Pengabdian Pada Masyarakat Mnerangi Negeri, 2(2), 90-99. https://doi.org/10.33322/terang.v2i2.372

Helaluddin, \& Awalludin. (2020). Keterampilan Menulis Akademik Panduan Bagi Mahapeserta didik di Perguruan Tinggi. Banten: Media Madani.

Jariah, A. (2021). Penerapan Teori Belajar Piaget untuk Meningkatkan Prestasi Belajar Peserta didik Kelas VII pada Mata Pelajaran PKN di SMP Negeri 1 Brang Rea Tahun Pelajaran 2020/2021. Jurnal LENTERA: Jurnal Studi Pendidikan, 3(1), 1-12.

Kristanto, V. H. (2018). Metodologi Penelitian Pedoman Penulisan Karya Tulis Ilmiah: (KTI). Yogyakarta: Deepublish.

Setiyo, M. (2021). Tips Menyusun Artikel Ilmiah Hasil Penelitian (Original Research Paper) yang Akuntabel bagi Peneliti Pemula. Community Empowerment, 6(1), 81-90. https://doi.org/https://doi.org/10.31603/ce.44 23

Slameto, S. (2016). Penulisan Artikel Ilmiah Hasil Penelitian Tindakan Kelas. Scholaria : Jurnal Pendidikan Dan Kebudayaan, 6(2), 46-57. https://doi.org/10.24246/j.scholaria.2016.v6. 
i2

Sujana, I. W. C. (2019). Fungsi Dan Tujuan Pendidikan Indonesia. Adi Widya: Jurnal Pendidikan Dasar, 4(1), 29-37. https://doi.org/http://doi.org/10.25078/aw.v4 i1.927

Sumardi, A., Susanto, A., \& Yulianti, S. (2020). Pengaruh Media Buku Saku untuk Meningkatkan Keterampilan Menulis Teks Eksposisi Kelas X MAN 4 Jakarta. Prosiding Seminar Nasional Penelitian LPPM UMJ, 110.https://jurnal.umj.ac.id/index.php/semnasl it/article/view/8779/5141

Susetyo, S., Basuki, R., \& Noermanzah, N. (2020).
Peningkatan Profesionalisme Guru Bahasa Indonesia di Kabupaten Musirawas Sumatera Selatan Melalui Pelatihan Menulis Artikel Jurnal Ilmiah. ABDI: Jurnal Pengabdian Dan Pemberdayaan Masyarakat, 2(1), 28-34. https://doi.org/10.24036/abdi.v2i1.35

Winarto, W, W, A. (2021). Program Peningkatan Minat Menulis Karya Tulis Ilmiah Mahapeserta didik. JURNAL ALTIFANI Penelitian Dan Pengabdian Kepada Masyarakat, $\quad 1(1), \quad 22-26$. https://doi.org/https://doi.org/10.25008/altifa ni.v1i1.114 